\title{
Evaluation of in-vivo antidiarrhoeal and in- vitro antibacterial activities of the root extract of Brucea antidysenterica J. F. Mill (Simaroubaceae)
}

\author{
Kaleab Alemayehu Zewdie* D, Dayananda Bhoumik@, Dawit Zewdu Wondafrash(D) and Kald Beshir Tuem(1)
}

\begin{abstract}
Background: Diarrhoea has been the major cause of death especially in children of developing countries. Brucea antidysenterica is one of the several medicinal plants used traditionally for the treatment of diarrhoea in Ethiopia. Hence, the present study was undertaken to investigate the antidiarrhoeal and antibacterial activities of the root extract of B. antidysenterica.

Methods: Plant material was extracted by maceration technique using $80 \%$ methanol. The antidiarrhoeal activity was tested using castor oil-induced diarrhoea, castor oil-induced charcoal meal test, and castor oil-induced enteropooling models in mice. Whilst, the antibacterial activity of the crude extract was evaluated using agar well diffusion and broth microdilution methods.

Results: The $80 \%$ methanolic crude extract significantly delayed the diarrhoeal onset at the two higher doses $(p<$ 0.001 ) and it has also inhibited the number and weight of faecal output at all tested doses as compared with the negative control. Moreover, it showed a significant anti-motility effect $(p<0.001)$ at all tested doses. Whereas it displayed a significant reduction in the weight and volume of intestinal contents at the doses of 200 and $400 \mathrm{mg} /$ $\mathrm{kg}(p<0.01)$. The highest concentration $(800 \mathrm{mg} / \mathrm{mL})$ of test extract showed maximum zone of inhibition in all tested standard strains of bacteria $(18.3 \mathrm{~mm}-22 \mathrm{~mm})$. While MIC and MBC values $(0.39 \mathrm{mg} / \mathrm{mL}$ and $1.56 \mathrm{mg} / \mathrm{mL})$ showed that $S$. flexneri was the most susceptible pathogen for test extract.
\end{abstract}

Conclusion: The study revealed that the root extract of B. antidysenterica has antidiarrhoeal and antibacterial activities.

Keywords: Antidiarrhoeal, Antibacterial, Castor oil, Agar well diffusion, Brucea antidysenterica

\section{Background}

Diarrhoea is a loss of watery stool at least three times a day [1], or more frequent bowel movements with a volume or weight of greater than $200 \mathrm{~mL}$ or $200 \mathrm{~g}$ in $24 \mathrm{~h}$ duration [2,3]. Although diarrhoea is a preventable

\footnotetext{
* Correspondence: kalxy2919@gmail.com

Department of Pharmacology and Toxicology, School of Pharmacy, Mekelle University, 1871 Mekelle, Ethiopia
}

condition, it affects almost all global population and accountable for $5 \%$ of health defects and $4 \%$ of all deaths worldwide [4]. Globally, about 2.2 million people died each year and most are due to bacterial-induced diarrhoea. Several bacterial pathogens including Vibrio cholera, Clostridium difficile, Shigella species, Escherichia coli, Pseudomonas aeruginosa and Salmonella species causes various forms of diarrhoea [5, 6]. According to the Centre for Disease Control and Prevention (CDC) and WHO 
report in 2017, 1 in 9 child death was reported worldwide, which makes diarrhoea the second leading cause of death for under-five children [1,5]. Moreover, diarrhoea kills 2195 children each day which is greater than malaria, measles and AIDS combined [5, 7].

Since primaeval times, humans used natural products to relieve and treat diseases for themselves and their livestock. Different traditional plants have been used as a source of modern medicine [8, 9]. In addition, numerous traditional plants were scientifically reported for their antidiarrhoeal activity:- including Myrtus communis [10], Lantana camara [11], Croton macrostachyus [12], Carissa carandas [13], Zehneria scabra [14], Ajuga remota [15], Discopodium penninervum [16] and Lepidium sativum [17].

Brucea antidysenterica J. F. Mill (Family: Simaroubaceae) belongs to genus Brucea. It is a small tree, widely distributed in tropical America and Africa [18]. The family Simaroubaceae comprises about 25 genera, 120 species and in the genus Brucea about 10 species are found in Africa, Asia, and Australia. B. antidysenterica is mostly found in Ethiopia and well-known for its medicinal uses $[19,20]$. It has been reported for several ethnomedicinal uses such as malaria [20], bacterial infections [21-23], dysentery [24] and amoebicidal effect [25].

The anti-diarrhoeal claims of $B$. antidysenterica were stated in numerous works of literature [26-29]. The bark, fruit, and roots of $B$. antidysenterica have been used by traditional society against dysentery, as an anthelmintic and for treatment of fever. The seed, leaf and roots are used as a remedy for diarrhoea, indigestion, and stomach-ache $[26,29]$. The present study was investigated to assess the antidiarrhoeal and antibacterial activities of the $80 \%$ hydro-methanolic root extract of $B$. antidysenterica in laboratory-based studies.

\section{Methods}

\section{Drugs and chemicals}

Castor oil (Amman Pharmaceutical industries CO, Jordan), activated charcoal (Research-Lab fine Chem industries, Mumbai, India), loperamide (Daehwa Pharmaceuticals, Republic of Korea), distilled water (Dallul Pharmaceuticals PLC, Addis Ababa, Ethiopia), methanol (Alpha Chemika, Mumbai, India), ciprofloxacin $5 \mu \mathrm{g} /$ disc (Becton, Dickinson and Company, Sparks, USA), ceftazidime $30 \mu \mathrm{g} / \mathrm{disc}$ (Oxoid Ltd., Basingstoke, England), muller hinton agar (MHA) (HiMedia Laboratories Pvt. Ltd., India), muller hinton broth (MHB) (HiMedia Laboratories Pvt. Ltd., India) and nutrient agar (Micro master lab, India) were used during the study.

\section{List of materials}

The following materials were used for the study. Electrical grinder (Shanghai Yuan Wo industrial and trade
CO. LTD, Shanghai city), orbital shaker (Stuart S01, UK), drying oven (M200CFL, England), vortex mixer (Assistant Reamix 2789, Germany) and Bio-safety Cabinet (Bio- II- A/P, Telstar Company, Italy).

\section{Collection and authentication of plant material}

The roots of $B$. antidysenterica were collected from one of the claimed areas 'Lumame', in Gozamin Wereda, east Gojjam zone of Amhara region, Ethiopia in November 2018. Identification and authentication of the plant material was done by Professor Sileshi Nemomissa, an authorized botanist at the National Herbarium, College of Natural and Computational Sciences, Addis Ababa University, and the sample were deposited for future reference with voucher specimen number 1 .

\section{Preparation of crude extract}

The collected root was washed gently and dried at room temperature under shade. It was then chopped manually and ground with an electrical grinder. The extraction was done by maceration technique with $80 \%$ methanol solvent, in the 1:6 solute-solvent ratio. The extraction was facilitated by intermediate manual shaking and occasional quivering with an orbital shaker at $120 \mathrm{rpm}$. After $72 \mathrm{~h}$, the macerate was filtered with a double-layered muslin cloth and Whatman number 1 filter paper. The marc was remacerated twice with fresh solvent for exhaustive extraction. The combined extract was dried under $40{ }^{\circ} \mathrm{C}$ in a drying oven. After drying, the percentage yield of plant extract was determined and it was $6.26 \% \mathrm{w} / \mathrm{w}$. Finally, the dried crude extract was stored in the refrigerator at $4{ }^{\circ} \mathrm{C}$ until use [20].

\section{Experimental animals}

Healthy Swiss albino mice of either sex (weighing 25-35 $\mathrm{g}$ and age of 6-8 weeks) were used for the experiment. The animals were obtained from and maintained in the laboratory of Department of Pharmacology and Toxicology, School of Pharmacy, Mekelle University. All animals were housed in plastic cages at room temperature in an air-conditioned room of 12-h light/dark cycle with accesses of pellet diet and clean water ad libitum. Before any experiment was started animals were allowed a week of acclimatization to the experimental environment and all the experiments were carried out according to the internationally accepted laboratory animal care and use guideline [30, 31]. The protocol approval letter was obtained from the Health Research Ethics Review Committee (HRERC) of College of Health Sciences, Mekelle University and registered as ERC 1537/2018 protocol number on December 11, 2018. 


\section{Acute Oral toxicity test}

Acute oral toxicity test was performed based on the Organization for Economic Cooperation and Development (OECD) guideline, number 425. All animals were observed continuously for toxicities like diarrhoea, decrease of appetite, hair erection and loss, lacrimation, convulsion, salivation, lethargy, paralysis, and mortality for the first 1 hour continuously and intermittently for the next 3 hours and periodically for $24 \mathrm{~h}$ and later cage side observation continued for 14 days [31].

\section{Grouping and dosing of animals}

Mice were randomly assigned into five groups of six animals each to perform antidiarrhoeal activity using three models. The negative control groups were treated with distilled water (DW) $(10 \mathrm{~mL} / \mathrm{kg})$, positive control groups received the standard drug loperamide $(3 \mathrm{mg} / \mathrm{kg})$ in all models. The three tested doses were selected based on the result of acute toxicity study. Based on that 100, 200 and $400 \mathrm{mg} / \mathrm{kg}$ were considered as low dose, middle dose and high dose, respectively. A volume of $1 \mathrm{~mL} / 100 \mathrm{~g}$ was administered orally based on individual mouse body weight [31]. The duration of administration was depending on the type of test and it was described along with the respective models.

\section{Determination of anti-diarrhoeal activity Castor oil induced Diarrhoea model}

This model was conducted according to Degu et al., and Sisay et al., $[10,12]$. Animals were fasted for $18 \mathrm{~h}$ and placed individually in a cage, in which the bottom floor was lined with blotting paper and was replaced every hour. Then animals received either vehicle or treatment samples as described in section 2.7 based on their fasting weight. Diarrhoea was induced by administering $0.5 \mathrm{~mL}$ of castor oil per oral route to each mouse just $1 \mathrm{~h}$ after the previous treatments. The observation was continued for a period of $4 \mathrm{~h}$. Time of onset of diarrhoea, a total number of faecal outputs (frequency of defecation) and weight of faeces excreted by the animals were recorded. Finally, the percentage of diarrhoeal inhibition, percentage weight of wet faecal output and percentage weight of total faecal output were determined with respect to their formula $[10,12,14]$.

$\%$ Inhibition $=\frac{\text { Average number of WFC }- \text { Average number of WFT }}{\text { Average number of WFC }} \times 100$

Where, WFC = average number of wet faeces in the control group and

WFT = average number of wet faeces in the test group.

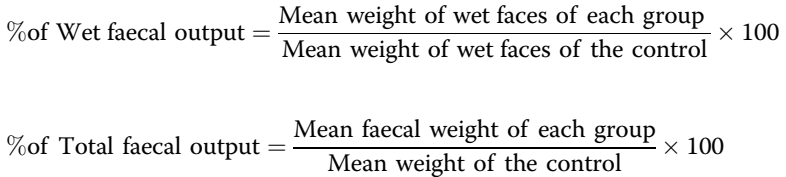

\section{Castor oil induced charcoal meal test}

Gastrointestinal motility test by using activated charcoal was done in accordance with Sisay et al., [10]. Mice of either sex were fasted for $18 \mathrm{~h}$ with free access to water and treated with the vehicle, standard drug and plant extract according to their respective group as described in section 2.7 based on their fasting weight by oral gavage. After 1 hour of test/ vehicle compound administration, $0.5 \mathrm{~mL}$ castor oil was administered by oral gavage then $1 \mathrm{~mL}$ of $5 \%$ charcoal suspension was administered orally 1 hour after castor oil treatment. After 1 hour of the charcoal meal, animals were sacrificed by cervical dislocation and the small intestine was dissected out and later the total length covered by a charcoal indicator from the pylorus to cecum was measured and calculated as a percentage of the total length of the small intestine. Finally, the Peristalsis index and proportion of inhibition were calculated by using the following formula $[10,12,32]$.

$$
\begin{gathered}
\text { Peristaltic index }=\frac{\text { Mean distance travelled by charcoal meal }}{\text { Mean length of small intestine }} \times 100 \\
\% \text { of inhibition }=\frac{\text { PIC-PIT }}{\text { PIC }} \times 100
\end{gathered}
$$

Where, PIC $=$ Peristaltic index of control; PIT $=$ Peristaltic index of the test group

\section{Castor oil induced Enteropooling model}

The intraluminal fluid accumulation (enteropooling) was carried out based on a method described by Sisay et al., [10]. Mice were grouped as described earlier and fasted for $18 \mathrm{~h}$ prior to the experiment. Then the test compound and vehicle were given according to their grouping based on their fasting weight by oral gavage 1 hour prior to castor oil administration. After 1 hour all mice were sacrificed by cervical dislocation, and then the small intestine was isolated and tied with thread at the pyloric end and the ileocaecal junction. Then the weight of filled intestine was measured and the content was drained into a graduated cylinder and volume was measured, later the weight of empty intestine was remeasured again and the change in the full and empty intestine was calculated. Finally, the percentage reduction of intestinal discharge (volume) and weight of intestinal content were calculated by comparing with a negative control by the following formula $[10,12]$. 
Mean Percentage volume inhibition

$$
=\frac{\text { MVICC }- \text { MVICT }}{\text { MVICC }} \times 100
$$

Where, MVICC is the Mean volume of the intestinal content of the control group

MVICT is the Mean volume of the intestinal content of the test group.

$$
\begin{gathered}
\text { Mean Percentage weight inhibition } \\
=\frac{\text { MWICC }- \text { MWICT }}{\text { MWICC }} \times 100
\end{gathered}
$$

Where, MWICC is the Mean weight of the intestinal content of the control group

MWICT is the Mean weight of the intestinal content of the test group.

\section{In vivo anti-Diarrhoeal index}

The in vivo anti-diarrhoeal index (ADI) was determined by combining three parameters taken from the abovementioned models. It was then expressed according to the following formula developed by Aye-than et al., [33].

$$
\mathrm{ADI}=\sqrt[3]{\text { Dfreq } X \text { Gmeq } X \text { Pfreq }}
$$

Where, Dfreq is the delay in defecation time as a percentage of negative control,

Gmeq is the gut meal travel reduction as a percentage of negative control.

Pfreq is the reduction in purging frequency in the number of wet stools as a percentage of the negative control.

$$
\text { Dfreq }=\frac{\text { MODTG-MODCG }}{\text { MODCG }}
$$

Where, MODTG is Mean onset of diarrhoea in the test group

MODCG is Mean onset of diarrhoea in the control group

\section{Antibacterial activity test \\ Media preparation and inoculum standardization}

The standard bacterial medium was prepared and used according to the manufacturers' guidelines. According to the Clinical and Laboratory Standard Institute (CLSI), the bacterial turbidity of each species was prepared and standardized. The turbidity of the inoculum tube was adjusted visually by the naked eye against a $0.5 \mathrm{McFar}-$ land turbidity equivalence with white background and contrasting black lines in the presence of adequate light by either adding colonies or sterile normal saline solution. It is assumed to contain a bacterial concentration of $1 \times 10^{8} \mathrm{CFU} / \mathrm{mL}$. Then, the standardized suspension was used within $15 \mathrm{~min}$ of its preparation [34].

\section{Agar well diffusion method}

The antibacterial activity of the crude root extract of $B$. antidysenterica was done according to Umer et al., and Molla et al., [32, 35]. It was performed on both American type cell culture (ATCC) and clinical isolates of selected intestinal pathogens obtained from Ayder comprehensive specialized hospital, which were considered as a major cause of diarrhoea such as Shigella flexneri (S. flexneri) (ATCC-12022), Salmonella typhi (S. typhi) (ATCC-13062), Salmonella species (clinical isolate), E. coli (ATCC-25922), E. coli (Clinical isolate) and P. aeruginosa (ATCC-27853).

Three test concentrations of plant extract $(800 \mathrm{mg} /$ $\mathrm{mL}, 400 \mathrm{mg} / \mathrm{mL}$ and $200 \mathrm{mg} / \mathrm{mL}$ ), vehicle and standard antibiotic disc were used for determining zone of inhibition. Ceftazidime $(30 \mu \mathrm{g} / \mathrm{disc}$, for $P$. aeruginosa) and ciprofloxacin $(0.005 \mathrm{mg} / \mathrm{disc}$, for the remaining bacteria) were used as a standard drug and distilled water was used as a negative control. The standard antibacterial discs were selected based on the susceptibility of bacterial species [36]. The antibacterial activity was evaluated by measuring the zone of inhibition against the test organisms by using vernier calliper and then compared with the reference as well as the control. Each procedure was done in triplicates and average values were being taken for further use [32, 35].

\section{Determination of the minimum inhibitory concentration}

Microdilution broth method was used for determining minimum inhibitory concentration (MIC) [21, 35]. MIC was performed for the test extract that showed acceptable $(>7 \mathrm{~mm})$ antibacterial activity in agar well diffusion assay [21]. The plant extract concentration was ranged from $50 \mathrm{mg} / \mathrm{mL}$ to $0.0975 \mathrm{mg} / \mathrm{mL}$ for $S$. flexneri and from 200 to $0.39 \mathrm{mg} / \mathrm{mL}$ for the remaining bacteria in a descending order from first to tenth column.

The 96 well plates were used for resazurin-based microtitre dilution assay. The lowest concentration of test extract at which no colour change occurred was recorded as the MIC value [21, 35]. Each procedure was carried out in triplicates and average values were taken. In this experimentation, each microtiter plate had a set of two controls. One of the controls was growth control (colour contrast control) which contained all solution except the plant extracts (11th column). It was used to determine the growth of bacteria. The other control was sterility control which was the 12th column contained media and resazurin solution. The sterility control was used to know the sterility of the procedure (the media and resazurin solution). Finally results were compared with reference drug in the CLSI guideline and other literatures [34]. 
Determination of minimum bactericidal concentration

The minimum bactericidal concentration (MBC) was determined by sub-culturing the contents of wells from the MIC results for individual bacterium as done by previous literature [21, 35]. In this method, the contents of all wells resulting in MIC and all concentrations above MIC were streaked using a sterile wire loop on MHA. Then it was incubated at $37^{\circ} \mathrm{C}$ for $24 \mathrm{~h}$. The lowest concentration of the extract which showed no bacterial growth was distinguished and verified as the MBC. All procedures were conducted in triplicates and the average value was taken for the $\mathrm{MBC}$ of test material against each bacterium.

\section{Preliminary phytochemical screening}

The qualitative phytochemical screening for the crude root extract of $B$. antidysenterica were done by using standard chemical tests [12, 37].

\section{Statistical analysis}

Results were expressed in mean \pm standard error of the mean (SEM) and comparisons were made between negative control, positive control and treatment groups of various doses using one-way analysis of variance (ANOVA) followed by posthoc Tukey's test using statistical package for the social sciences (SPSS) version 20.0. All data were analyzed at $95 \%$ confidence interval and $P$ values less than 0.05 was considered as statistically significant. Coefficient of determination (linear regression analysis) $\left(R^{2}\right)$, was also determined by using Microsoft excel 2013. The analyzed data were presented using tables and figures.

\section{Results}

Acute Oral toxicity test

After a single oral administration of limit dose (2000 $\mathrm{mg} / \mathrm{kg}$ ), animals did not show any change in motor activity, lacrimation, diarrhoea, convulsion, and coma. In addition, no physical, behavioural and neurological changes were recorded. During the total period of acute toxicity study, none of the animals show any change in weight and appetite (food and water intake). No mortality was also recorded during the total 14 days of the observation period.

\section{Anti-diarrhoeal activity \\ Effects on Castor oil induced Diarrhoea in mice}

The crude root extract of $B$. antidysenterica showed a dose-dependent response in prolonging the onset of diarrhoea. As shown in Table 1, the onset of diarrhoea was significantly protracted at doses of 200 and $400 \mathrm{mg} /$ $\mathrm{kg}$ as compared to the negative control $(p<0.001)$. In addition, the largest test dose has shown maximum prolongation in diarrhoeal onset as compared to the standard drug loperamide $3 \mathrm{mg} / \mathrm{kg}$. Moreover, all test doses of the crude root extract significantly decreased $(p<0.001)$ the average number and weight of wet faces as compared to the negative control.

As presented in Fig. 1, the dose-dependent decrement in percentage weight of wet faecal output and percentage weight of the total number of faecal outputs were recorded. The largest dose showed the highest inhibition of defecation $(88.89 \%)$, the lowest percentage of mean wet faecal output (14.07\%) and a total number of faecal output $(22.79 \%)$ as compared with all tested doses of the extract and positive control $(p<0.001)$.

\section{Effects on Castor oil induced intestinal transit in mice}

Results from the charcoal meal intestinal transit model revealed that the crude extract of $B$. antidysenterica showed significant inhibition of intestinal transit at all test doses. The maximum antimotility effect was recorded in the highest dose of test extract $400 \mathrm{mg} / \mathrm{kg}$ $(67.59 \%)$, which is comparable with the standard drug loperamide $3 \mathrm{mg} / \mathrm{kg}(67.35 \%, p<0.001)$ (Table 2).

\section{Effects on Castor oil induced Enteropooling}

The $80 \%$ hydro-methanolic crude root extract of $B$. antidysenterica showed a significant reduction in both average weight and volume of intestinal contents as

Table 1 The Antidiarrhoeal effects of the root extract of B. antidysenterica on castor oil-induced diarrhoeal model in mice

\begin{tabular}{|c|c|c|c|c|c|c|c|}
\hline & $\begin{array}{l}\text { Dose } \\
\text { Administered } \\
\end{array}$ & $\begin{array}{l}\text { Onset of Diarrhoea } \\
\text { (Min) }\end{array}$ & $\begin{array}{l}\text { No of wet } \\
\text { faeces }\end{array}$ & $\begin{array}{l}\text { Total No of } \\
\text { faeces }\end{array}$ & $\begin{array}{l}\text { Average weight of wet } \\
\text { faeces (gm) }\end{array}$ & $\begin{array}{l}\text { Average weight of total } \\
\text { faeces (gm) }\end{array}$ & $\begin{array}{l}\% \\
\text { Reduction }\end{array}$ \\
\hline \multirow{5}{*}{$\begin{array}{l}80 \% \\
\text { BAE }\end{array}$} & DW 10 mL/kg & $76.17 \pm 2.07$ & $7.5 \pm 0.43$ & $8.17 \pm 0.48$ & $0.76 \pm 0.04$ & $0.83 \pm 0.05$ & - \\
\hline & $\begin{array}{l}\text { Loperamide } 3 \\
\mathrm{mg} / \mathrm{kg}\end{array}$ & $166.33 \pm 6.97^{\mathrm{a} 3 c 3}$ & $\begin{array}{l}1.33 \pm \\
0.33^{\mathrm{a} 3 \mathrm{c} 3}\end{array}$ & $\begin{array}{l}2.67 \pm \\
0.42^{\mathrm{a} 3 c 2}\end{array}$ & $0.14 \pm 0.03^{\mathrm{a} 3 \mathrm{c} 2}$ & $0.23 \pm 0.05^{\mathrm{a} 3 \mathrm{c} 2}$ & $82.22 \%$ \\
\hline & BAE $100 \mathrm{mg} / \mathrm{kg}$ & $89.50 \pm 2.50^{\mathrm{b} 3 \mathrm{~d} 3 \mathrm{e} 3}$ & $\begin{array}{l}3.5 \pm \\
0.22^{\mathrm{a} 3 \mathrm{~b} 3 \mathrm{~d} 3 \mathrm{e} 3}\end{array}$ & $\begin{array}{l}4.83+ \\
0.31^{\mathrm{a} 3 \mathrm{~b} 2 \mathrm{e} 2}\end{array}$ & $0.38 \pm 0.04^{\text {a3b2d1e } 3}$ & $0.50 \pm 0.05^{\mathrm{a} 3 \mathrm{~b} 2 \mathrm{e} 2}$ & $53.33 \%$ \\
\hline & BAE $200 \mathrm{mg} / \mathrm{kg}$ & $151.00 \pm 3.17^{\mathrm{a} 3 c 3 e 2}$ & $\begin{array}{l}1.33 \pm \\
0.21^{\mathrm{a} 3 \mathrm{c} 3}\end{array}$ & $3.33 \pm 0.33^{\mathrm{a} 3}$ & $0.18 \pm 0.03^{\mathrm{a} 3 \mathrm{c} 1}$ & $0.31 \pm 0.04^{\mathrm{a} 3}$ & $82.22 \%$ \\
\hline & BAE $400 \mathrm{mg} / \mathrm{kg}$ & $172.67 \pm 3.48^{\mathrm{a} 3 \mathrm{c} 3 \mathrm{~d} 2}$ & $\begin{array}{l}0.83 \pm \\
0.31^{\mathrm{a} 3 \mathrm{c} 3}\end{array}$ & $\begin{array}{l}2.17 \pm \\
0.40^{\mathrm{a} 3 \mathrm{c} 2}\end{array}$ & $0.11 \pm 0.04^{\mathrm{a} 3 \mathrm{c} 3}$ & $0.19 \pm 0.05^{\mathrm{azc} 2}$ & $88.89 \%$ \\
\hline
\end{tabular}

Data's are mean \pm SEM $(n=6) ;{ }^{\text {a }}$ compared with negative control values; ${ }^{\mathrm{b}}$ compared with loperamide; ${ }^{\mathrm{c}}$ compared with $100 \mathrm{mg} / \mathrm{kg}^{2}{ }^{\mathrm{d}}$ compared with $200 \mathrm{mg} / \mathrm{kg} ;{ }^{\mathrm{e}}$ compared with $400 \mathrm{mg} / \mathrm{kg} ;{ }^{1} p<0.05,{ }^{2} p<0.01,{ }^{3} p<0.001 ;$ DW Distilled water, BAE B. antidysenterica extract 


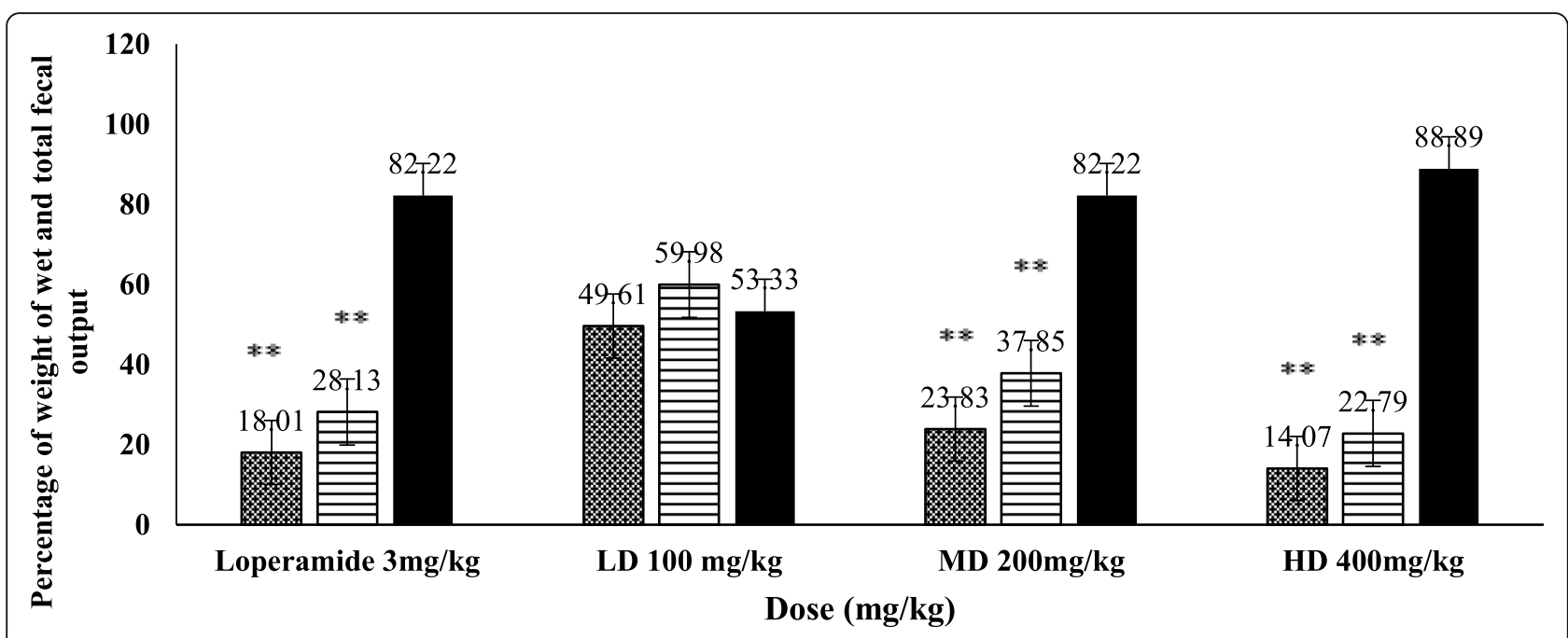

\% \% Weight of Wet fecal output $\quad \square \%$ Weight of Total fecal output $\quad$ a\% inhibition

Fig. 1 Percentage weight faecal output inhibition of the root extract of $B$. antidysenterica in castor oil-induced model. LD, low dose; MD, middle dose; HD, high dose; ${ }^{* *} p<0.001$

compared with the negative control. Significant inhibition of intestinal milked volume was recorded on 200 $\mathrm{mg} / \mathrm{kg}(p<0.05)$ and $400 \mathrm{mg} / \mathrm{kg}(p<0.01)$ test dose relative to the negative control group. The highest dose of test extract $400 \mathrm{mg} / \mathrm{kg}$ showed comparable result $(37.76 \%, p<0.01)$ as of standard drug Loperamide $3 \mathrm{mg} /$ $\mathrm{kg}(39.80 \%, p<0.01)$ (Table 3$)$.

The other parameter recorded in this model was percentage inhibition in the average weight of intestinal contents. As shown in Table 3, significant inhibition were recorded in 200 and $400 \mathrm{mg} / \mathrm{kg}$ dose of test extract with percentage inhibition of $27.82 \%(p<0.05)$ and $32.56 \%(p<0.01)$ respectively. The highest level of intestinal fluid reduction was recorded in the standard drug loperamide $3 \mathrm{mg} / \mathrm{kg}$ (34.31\%), which is comparable with the highest dose of test extract.

\section{In vivo anti-diarrhoeal index}

As shown in Table 4, 32.04, 73.22 and $87.6 \%$ were recorded as in vivo ADI for 100, 200 and $400 \mathrm{mg} / \mathrm{kg}$ dose of test extract. The $400 \mathrm{mg} / \mathrm{kg}$ dose showed the highest in vivo anti-diarrhoeal index, which is comparable to the standard drug loperamide $3 \mathrm{mg} / \mathrm{kg}$ dose (83.07\%).

\section{Antibacterial activity \\ Antibacterial zone of inhibition}

The concentration-dependent effect $\left(R^{2}\right)$ values were calculated for each bacterial species accordingly, $R^{2}$ of $80 \%$ methanolic extract was $0.873,0.890,0.930$ and 0.987 , for ATCC strain of S. typhi, E. coli, P. aeruginosa and S. flexneri respectively. The maximum average zone of inhibition was recorded at $800 \mathrm{mg} / \mathrm{mL}$ concentration of test extract as 22.0, 20.7, 19.3 and $18.3 \mathrm{~mm}$ for ATCC strains of $P$. aeruginosa, S. flexneri, S. typhi and E. coli respectively. On the contrary, no bacterial growth inhibition was observed in all concentrations of $80 \%$ methanolic extract against clinical isolates of E. coli and Salmonella species.

In Table 5, the mean comparison of different concentrations of extract within a group and with the standard antibacterial disc was presented. As shown in the table, all concentrations of plant extract showed a statistically

Table 2 The effects of root extract of B. antidysenterica on gastrointestinal transit in mice

\begin{tabular}{|c|c|c|c|c|c|}
\hline Extract & Dose Administered & Length of small intestine $(\mathrm{cm})$ & Distance covered by charcoal meal $(\mathrm{cm})$ & Peristaltic index (\%) & $\%$ Inhibition \\
\hline \multirow[t]{5}{*}{$80 \%$ BAE } & DW $10 \mathrm{~mL} / \mathrm{kg}$ & $57.50 \pm 0.43$ & $50.33 \pm 0.84$ & $87.56 \pm 1.61$ & - \\
\hline & Loperamide 3 mg/kg & $57.83 \pm 0.83$ & $16.50 \pm 0.76^{\mathrm{azc} \mathrm{cd} 3}$ & $28.59 \pm 1.50^{\mathrm{a} 3 \mathrm{c} 3 \mathrm{~d} 3}$ & 67.35 \\
\hline & BAE $100 \mathrm{mg} / \mathrm{kg}$ & $57.83 \pm 0.79$ & $30.83 \pm 0.67^{\mathrm{a} 3 \mathrm{~b} 3 \mathrm{~d} 3 \mathrm{e} 3}$ & $53.30 \pm 0.67^{\text {aзb3 } а 3 е 3}$ & 39.13 \\
\hline & BAE 200 mg/kg & $58.33 \pm 0.54$ & $22.83 \pm 0.84^{\text {азьвзсзез }}$ & $39.11 \pm 1.18$ азьзсзез & 55.34 \\
\hline & BAE $400 \mathrm{mg} / \mathrm{kg}$ & $56.83 \pm 0.48$ & $16.17 \pm 1.19^{\mathrm{a3c3d} 3}$ & $28.38 \pm 1.87^{\mathrm{a} 3 \mathrm{c} 3 \mathrm{~d} 3}$ & 67.59 \\
\hline
\end{tabular}

Data's are mean \pm SEM $(n=6) ;{ }^{\text {a }}$ compared with negative control values; ${ }^{b}$ compared with loperamide; ${ }^{\mathrm{c}}$ compared with $100 \mathrm{mg} / \mathrm{kg}^{\circ}{ }^{\mathrm{d}}$ compared with $200 \mathrm{mg} / \mathrm{kg} ;{ }^{\mathrm{e}}$ compared with $400 \mathrm{mg} / \mathrm{kg} ;{ }^{1} p<0.05,{ }^{2} p<0.01,{ }^{3} p<0.001 ; D W$ distilled water, BAE B. antidysenterica extract 
Table 3 The effects of the root extract of B. antidysenterica on gastrointestinal fluid accumulation in mice

\begin{tabular}{llllll}
\hline Extract & Dose Administered & Volume of intestinal contents $(\mathrm{mL})$ & \% Inhibition & Weight of intestinal contents $(\mathrm{gm})$ & $\%$ Inhibition \\
\hline $80 \% \mathrm{BAE}$ & DW $10 \mathrm{~mL} / \mathrm{kg}$ & $0.82 \pm 0.03$ & - & $1.07 \pm 0.04$ & - \\
& Loperamide $3 \mathrm{mg} / \mathrm{kg}$ & $0.49 \pm 0.04^{\mathrm{a} \mathrm{cc} 2}$ & 39.80 & $0.71 \pm 0.03^{\mathrm{a} 2}$ & 34.31 \\
& BAE $100 \mathrm{mg} / \mathrm{kg}$ & $0.71 \pm 0.03^{\mathrm{b} 2 \mathrm{e} 2}$ & 13.27 & $0.90 \pm 0.09$ & 16.25 \\
& BAE $200 \mathrm{mg} / \mathrm{kg}$ & $0.57 \pm 0.05^{\mathrm{a} 3}$ & 30.61 & $0.78 \pm 0.06^{\mathrm{a} 1}$ & 27.82 \\
& BAE $400 \mathrm{mg} / \mathrm{kg}$ & $0.51 \pm 0.02^{\mathrm{a} 3 \mathrm{c} 2}$ & 37.76 & $0.72 \pm 0.06^{\mathrm{a2}}$ & 32.56 \\
\hline
\end{tabular}

Data's are mean \pm SEM $(n=6) ;{ }^{a}$ compared with negative control values; ${ }^{b}$ compared with loperamide; ${ }^{c}$ compared with $100 \mathrm{mg} / \mathrm{kg}^{2}{ }^{\mathrm{d}}$ compared with $200 \mathrm{mg} / \mathrm{kg} ;{ }^{\mathrm{e}}$ compared with $400 \mathrm{mg} / \mathrm{kg} ;{ }^{1} p<0.05,{ }^{2} p<0.01,{ }^{3} p<0.001 ; D W$ distilled water, BAE B. antidysenterica extract

significant difference $(p<0.001)$ as compared with the positive control in all standard bacteria. In addition, the $200 \mathrm{mg} / \mathrm{mL}$ concentration of extract had significant difference $(p<0.01)$ for S. typhi and E. coli and $p<0.001$ for $P$. aeruginosa as compared with $400 \mathrm{mg} / \mathrm{mL}$ of crude extract. It had also a $p$-value $<0.001$ as compared with $800 \mathrm{mg} / \mathrm{mL}$ concentration for S. typhi, E. coli and P. aeruginosa while, the p-value is less than 0.01 for $S$. flexneri. In addition, the $400 \mathrm{mg} / \mathrm{kg}$ concentration of test extract showed a significant difference $(p<0.01)$ as compared with $800 \mathrm{mg} / \mathrm{mL}$ for $E$. coli and $P$. aeruginosa, while $p<$ 0.05 for $S$. flexneri.

\section{Minimum inhibitory concentration and minimum bactericidal concentration of crude extract against bacterial species}

According to the result obtained from 96 well microtiter plate microdilution test, the minimum inhibitory concentration of the crude extract against the tested species were less than or equal to $(\leq) 3.13 \mathrm{mg} / \mathrm{mL}$ for all tested bacteria species. As shown in Table 6, the lowest MIC of the crude root extract was recorded as $0.39 \mathrm{mg} / \mathrm{mL}$ for $S$. flexneri and the highest is for $P$. aeruginosa with a concentration of $3.13 \mathrm{mg} / \mathrm{mL}$.

As presented in Table 6 , the $\mathrm{MBC}$ values ranged from $1.56 \mathrm{mg} / \mathrm{mL}$ (S. flexneri) to $200 \mathrm{mg} / \mathrm{mL}$ (P. aeruginosa).

\section{Bacteriostatic/ bactericidal/ nature of the crude root extract} of $B$. antidysenterica

The bacteriostatic and bactericidal nature of the plant extract was also evaluated to assess its potential against bacterial strains. There are certain circumstances where cidal agents are preferable over static agents and vice versa [38]. Antibacterial substance is said to be bactericidal if the ratio of $\mathrm{MBC} / \mathrm{MIC}$ is $\leq 4$ and bacteriostatic if $\mathrm{MBC} / \mathrm{MIC}>4$ [39]. As presented in Table 6, except $P$. aeruginosa, the crude plant extract showed bactericidal activity. Moreover, extracts with MICs values between 0.1 and $0.625 \mathrm{mg} / \mathrm{mL}$ had moderate activity [40].

\section{Phytochemical constituents}

As presented in Table 7, the phytochemical analysis of the crude root extract of $B$. antidysenterica indicates the presence of different bioactive components.

$B A E$ B. antidysenterica extract, +: Present, -: Absent

\section{Discussion}

Diarrhoea is characterized by rapid and frequent passage of semisolid or liquid faecal material. It involves decreased in absorption of fluid, increased motility of the intestinal tract and increased secretions. In addition, diarrhoea leads to loss of electrolytes particularly sodium $\left(\mathrm{Na}^{+}\right)$and water, and finally end up with dehydration and death $[7,41,42]$.

$80 \%$ methanol was used as a macerating solvent for plant extraction and it was similar with other laboratory works done on $B$. antidysenterica $[20,21]$. In general, hydro-alcoholic co-solvents such as $80 \%$ methanol seem to possess the optimum solubility characteristics for initial crude extraction and provide high extraction yield $[10,43]$. However, despite the several works interests in the polyphenols extraction, there is no single solvent

Table 4 In vivo antidiarrhoeal index of the root extract of B. antidysenterica

\begin{tabular}{llllll}
\hline Extract & $\begin{array}{l}\text { Dose } \\
\text { Administered }\end{array}$ & $\begin{array}{l}\text { Delay in defecation time } \\
\text { (Dfreq) } \\
(\%)\end{array}$ & $\begin{array}{l}\text { Gut meal travel distance } \\
\text { (Gmeq) (\%) }\end{array}$ & $\begin{array}{l}\text { Purging frequency in number of wet } \\
\text { stools (\%) }\end{array}$ & $\begin{array}{l}\text { In vivo Anti-diarrhoeal } \\
\text { Index (ADI) }\end{array}$ \\
\hline $\begin{array}{l}80 \% \\
\text { BAE }\end{array}$ & DW $10 \mathrm{~mL} / \mathrm{kg}$ & - & - & - & - \\
& $\begin{array}{l}\text { Loperamide 3 } \\
\mathrm{mg} / \mathrm{kg}\end{array}$ & 118.37 & 67.35 & 82.22 & 83.07 \\
& & & & 32.04 \\
& BAE $100 \mathrm{mg} / \mathrm{kg}$ & 17.50 & 39.13 & 53.33 & 73.22 \\
& BAE $200 \mathrm{mg} / \mathrm{kg}$ & 98.24 & 55.34 & 82.22 & 87.60 \\
\hline
\end{tabular}


Table 5 Zone of inhibition for the root extract of B. antidysenterica against selected diarrhoea causing bacteria

\begin{tabular}{|c|c|c|c|c|c|c|c|}
\hline Extract & Concentration & $\begin{array}{l}\text { S. flexneri (ATCC- } \\
12022) \\
(\mathrm{mm})\end{array}$ & $\begin{array}{l}\text { S. typhi (ATCC- } \\
13062) \\
(\mathrm{mm})\end{array}$ & $\begin{array}{l}\text { Salmonella Spp. } \\
(\mathrm{Cl}) \\
(\mathrm{mm})\end{array}$ & $\begin{array}{l}\text { E. coli (ATCC- } \\
25922) \\
(\mathrm{mm})\end{array}$ & $\begin{array}{l}\text { E. coli } \\
(\mathrm{Cl}) \\
(\mathrm{mm})\end{array}$ & $\begin{array}{l}\text { P. aeruginosa (ATCC- } \\
27853) \\
(\mathrm{mm})\end{array}$ \\
\hline \multirow[t]{3}{*}{$80 \%$ BAE } & $\begin{array}{l}\text { BAE } 200 \text { mg/ } \\
\mathrm{mL}\end{array}$ & $14.7 \pm 0.33^{\text {a3d } 2}$ & $14.7 \pm 0.33^{\mathrm{a} 3 \mathrm{c} 2 \mathrm{~d} 3}$ & NA & $14.0 \pm 0.00^{\mathrm{a} 3 \mathrm{c} 2 \mathrm{~d} 3}$ & NA & $16.7 \pm 0.33^{\text {aзc3d3 }}$ \\
\hline & $\begin{array}{l}\text { BAE } 400 \mathrm{mg} / \\
\mathrm{mL}\end{array}$ & $17.3 \pm 0.67^{\mathrm{a} 3 \mathrm{~d} 1}$ & $17.7 \pm 0.33^{\text {a3b2 }}$ & NA & $16.7 \pm 0.333^{\mathrm{a} 3 \mathrm{~b} 1 \mathrm{~d} 2}$ & NA & $19.7 \pm 0.33^{\text {a3b3d } 2}$ \\
\hline & $\begin{array}{l}\text { BAE } 800 \mathrm{mg} / \\
\mathrm{mL}\end{array}$ & $20.7 \pm 0.33^{\text {a3b2c1 }}$ & $19.3 \pm 0.33$ азb3 & NA & $18.3 \pm 0.33^{\text {a3b } 1 c 3}$ & NA & $22.0 \pm 0.00$ азьзс2 \\
\hline \multirow[t]{2}{*}{ Standards } & Cipro 5 mg/disc & $29.3 \pm 1.20$ & $34.3 \pm 0.67$ & $18.0 \pm 0.00$ & $32.3 \pm 0.33$ & NA & - \\
\hline & $\begin{array}{l}\text { Cefta } 30 \mu \mathrm{g} / \\
\text { disc }\end{array}$ & - & - & - & - & - & $10.3 \pm 0.33$ \\
\hline
\end{tabular}

Data are expressed as Mean \pm SEM $(n=3),{ }^{\text {a }}$ compared to positive control; ${ }^{b}$ compared to $200 \mathrm{mg} / \mathrm{mL}^{\mathrm{c}}{ }^{\mathrm{c}} \mathrm{compared}$ to $400 \mathrm{mg} / \mathrm{mL} ;{ }^{\mathrm{d}}$ compared to $800 \mathrm{mg} / \mathrm{mL} ;{ }^{1} P<$ $0.05,{ }^{2} P<0.01,{ }^{3} P<0.001$. The negative control has shown no antibacterial activity. The positive controls: BAE Brucea antidysenterica extract, Cipro Ciprofloxacin, Cefta Ceftazidime, NA No Activity

which may be considered standard because it is usually different for different plant matrices [43].

Castor oil-induced diarrhoeal model is the first model to assess the ability of test extract towards its antidiarrhoeal activity [12]. It causes an imbalance between the secretary and absorptive processes in the small intestine by producing inflammation and local irritation [10, 12, 44]. After oral administration, "ricinoleic acid" the active constituent of $\mathrm{CO}$, is released by intestinal lipases. Consequently, it activates intestinal smooth-muscle cells via endothelial prostanoid receptors $\left(\mathrm{EP}_{3}\right)$. Then it induces fluid and electrolyte secretion secondary to stimulation of an active anion secretory process, which is mediated by cAMP [45-47]. Therefore, the use of castor oil as diarrhoea inducer for all models is reasonable since it resembles the pathophysiologic processes and ensures the actual diarrhoeal (secretory and inflammatory diarrhoea) diseases in humans.

Results in this experiment verified that the crude root extract of $B$. antidysenterica showed a dosedependent response by prolonging the onset of diarrhoea on mice. The highest activity was seen in the two higher doses of test extract while the lower dose was devoid of significant prolongation. This might be associated with the smallest dose of test extract has not sufficient ability to prolong the onset of

Table 6 Minimum inhibitory concentration and minimum bactericidal concentration of $80 \%$ methanolic root extract of $B$. antidysenterica

\begin{tabular}{llll}
\hline $\begin{array}{l}\text { Bacterial } \\
\text { species }\end{array}$ & \multicolumn{3}{l}{$80 \%$ methanolic BAE } \\
\cline { 2 - 4 } & $\mathrm{MIC}(\mathrm{mg} / \mathrm{mL})$ & $\mathrm{MBC}(\mathrm{mg} / \mathrm{mL})$ & $\mathrm{MBC} / \mathrm{MIC}$ \\
\hline S. flexneri & $0.39 \pm 0.00$ & $1.56 \pm 0.00$ & 4.00 \\
S. typhi & $1.56 \pm 0.00$ & $3.13 \pm 0.00$ & 2.00 \\
E. coli & $2.08 \pm 0.52$ & $8.33 \pm 2.08$ & 4.00 \\
P. aeruginosa & $3.13 \pm 0.00$ & $200 \pm 0.00$ & 63.89 \\
\hline
\end{tabular}

Data are expressed as Mean $\pm \operatorname{SEM}(n=3) ; B A E$ B. antidysenterica extract diarrhoea. As explained by other reports doses having lower antimotility and/or antisecretory effects are less likely to address all the parameters [10, 12, 15].

The root extract of $B$. antidysenterica also significantly decrease the average number and weight of wet faces in the castor oil-induced diarrhoea model. Studies proved that an increase in stool frequency and volume showed the severity of diarrhoea and also a decreased in wet faces was used as a sign of recovery [48]. According to Degu et al, a decrease in stool frequency was associated with antisecretory and antimotility mechanisms, by which it decreases the number and weight of wet stool [12]. In addition, a study done by Lakshmanan et al, stated that the decreased in stool volume was mediated either by an antisecretory mechanism, reduction in intestinal muscle tone and/or decreased peristalsis of the gastrointestinal tract, which can slow the movement of faecal matter through the GI tract [49].

Gastrointestinal motility was significantly decreased at all test doses of crude extract. Different studies confirmed that the peristalsis in the GI system was increased in case of diarrhoea $[3,50]$. The reduction of GI peristalsis is one of the mechanisms by which antidiarrhoeal agents can act. For example, the standard drug (loperamide) used in this study acts by activation of $\mu$ receptors

Table 7 Phytochemical composition of the crude root extract of $B$. antidysenterica

\begin{tabular}{ll}
\hline Metabolites Tested & $80 \%$ methanolic BAE \\
\hline Alkaloids & + \\
Saponins & + \\
Tannins & + \\
Polyphenols & + \\
Terpenoids & + \\
Flavonoids & + \\
Anthroquinones & - \\
\hline
\end{tabular}


that inhibit the release of acetylcholine to enhance phasic colonic segmentation and inhibit peristalsis, thus increasing intestinal transit time [51]. The report was compared with similar reports done by Degu et al and Sisay et al $[10,12]$. All the test doses of plant extracts showed a significant decrement in peristaltic movement.

The third model in this study was castor oil-induced enteropooling model, which is aimed to assess the potential inhibition of secretory components in the gastrointestinal tract after castor oil administration for the induction of diarrhoea. Outcomes in this model proved that the $80 \%$ methanolic extract of $B$. antidysenterica showed a dose-dependent reduction in both average weight and volume of intestinal contents at all test doses as compared with the negative control. Even though the maximum effect was seen in the standard drug, the highest dose of plant extract exhibit a comparable effect. As described in Beubler, the gastrointestinal secretions secondary to castor oil administration are related to ricinoleic acid, which activates the nitric oxide pathway and induces nitric oxide (NO) dependent gut secretion along with prostaglandin synthesis. So that the possible mechanism is illustrated as inhibition of the nitric oxide pathway, by that it halts GI secretion [52].

The combined effect of antidiarrhoeal agents was generally investigated by calculating ADI [33]. As presented in Table 4, ADI values showed the dose-dependent nature of each parameter. The highest dose of the crude extract showed highest ADI as compared with corresponding doses and also better than the standard drug. This might be due to its better potential in prolongation of onset of diarrhoea, decrement of peristaltic movement and halting of purging frequency in the GI system as compared with the standard drug and respective doses.

Different mechanisms are hypothesized as a mechanism for the antidiarrhoeal effect of $B$. antidysenterica. Compounds inhibiting prostaglandin inhibition has an ability to prevent diarrhoea [53]. Similarly, a study done by Tessema et al, showed that $B$. antidysenterica has an anti-inflammatory effect, which might be attributed to inhibition of castor oil-induced prostaglandin synthesis and prevention of diarrhoea by inhibiting stimulation of intestinal secretions [54].

The other activity done in this study was the determination of antibacterial activity for selected diarrhoea causing bacteria. Based on the results obtained the highest antibacterial activity was observed in the highest concentration $(800 \mathrm{mg} / \mathrm{mL})$ of crude extract. The maximum zone of inhibition was recorded for ATCC strain of $P$. aeruginosa. Although the test extract has a smaller zone of inhibition as compared with the positive control in the case of S. flexneri, S. typhi and E. coli, it has better zone of inhibition for $P$. aeruginosa. This finding was inline with a study done on the leaf extract of $B$. antidysenterica [22]. According to Fentahun et al, the chloroform leaf extract of $B$. antidysenterica has showed highest $(11 \mathrm{~mm})$ zone of inhibition [22]. Other results done on different plants against $P$. aeruginosa showed that the zone of inhibition was ranging between 9 and $21 \mathrm{~mm}[23,32,35,55,56]$. This may indicate that the root extract of $B$. antidysenterica has been promising activity against $P$. aeruginosa and important to tackle diarrhoea secondary to chronic diseases.

The MIC and MBC results from this experiment showed that the root extract of $B$. antidysenterica has the ability to inhibit and kill bacteria. The MIC of an extract is regarded as good if the values are less than 0.1 $\mathrm{mg} / \mathrm{mL}$, moderate if it is between 0.1 and $0.625 \mathrm{mg} / \mathrm{mL}$ and weak when it is above $0.625 \mathrm{mg} / \mathrm{mL}[40,57]$. Based on this, the MIC of $80 \%$ hydro-methanolic crude extract of $B$. antidysenterica was ranged from moderate to weak against the tested bacteria strains. This might be related with their zone of inhibition during agar well diffusion assay. According to CLSI (2015a), compounds having a higher zone of inhibition has an ability to inhibit bacterial growth with a smaller concentration as compared with compounds having a low zone of inhibition. In addition, $\mathrm{MBC}$ of plant extract were one or more dilution factor greater than MIC values for each bacteria except for $P$. aeruginosa. It may indicate the sensitivity of test extract for those common diarrhoea causing bacteria [21]. However, $P$. aeruginosa is known to utilize its high level intrinsic and acquired resistance mechanisms to counter most antibiotics [58]. In addition, recent finding showed that biofilm-mediated resistance and formation of multidrug-tolerant persister cells are responsible for recalcitrance and relapse of infection [59]. On the other hand, the promising activity of plant extract against $S$. flexneri, $S$. typhi and E. coli might be used for treatment of bloody diarrhoea [60], inflammatory induced diarrhoea [61], traveller diarrhoea and food poisoning [62] respectively.

Results of phytochemical screening also support some of the aforementioned mechanisms listed above. According to similar studies done on different plants suggested that the presence of tannins and flavonoids increase colonic water and electrolyte reabsorption. Tannins are known for making intestinal mucosa more resistant by reducing secretion, normalizing deranged water transport and reduction of intestinal transit $[12,63]$. Other secondary metabolites like terpenoids and saponins also have the ability to inhibit the release of autacoids like prostaglandins and histamines [16]. Phytochemicals such as phenolic compounds and alkaloids also inhibit intestinal motility $[13,63,64]$. In addition, flavonoids are also found to display a wide range of biological activities including inhibition of enzymes such as prostaglandin synthase, cyclooxygenase and lipoxygenase that might mainly contribute to its anti-diarrhoeal activity [65]. 
The bioactive components, especially tannins and flavonoids, exert a major role on antibacterial activity. Different mechanisms are postulated for the action of these bioactive components. For example, tannins produce antibacterial activity by inactivating numerous enzymes, microbial adhesion, and cell envelope transport proteins [35]. Other active components like saponins have been reported to possess antibacterial activity, which could be attributed to their ability to form a complex with extracellular proteins, soluble proteins, and bacterial cell walls [55]. Other previous antibacterial studies also proved that the presence of these secondary metabolites has an important role in the inhibition of bacterial growth $[21,54,55]$.

\section{Conclusion}

Based on this study, the $80 \%$ hydro-methanolic root extract of $B$. antidysenterica had promising antidiarrhoeal and antibacterial activities. The overall antidiarrhoeal activity of the studied plant extract was associated with inhibitory effects on castor oilinduced gastrointestinal motility and fluid secretion. In addition, it has bactericidal activity against most of the studied bacteria. Further studies for solvent fractions, isolation of active principle (s), chemical standardization and elucidating the possible mechanism of action are recommended.

\section{Abbreviations}

ATCC: American type of cell culture; CFU: Colony-forming unit; CLSI: Clinical and laboratory standard institute; MBC: Minimum bactericidal concentration; MIC: Minimum inhibitory concentration; SPSS: Statistical package for the social sciences

\section{Acknowledgements}

We would like to thank Professor Sileshi Nemomissa for authenticating the plant material. We also thank Ethiopian Food and Drug Authority (EFDA), for providing active loperamide.

\section{Authors' contributions}

KAZ developed the proposal, conducted the experimental activities, analyzed the data, and drafted the manuscript. KBT, DB, DZW, and KAZ contributed to topic selection, design of the study, and data analysis and revised the manuscript for important intellectual content. All authors have read and approved the manuscript and agreed to be accountable for all aspects of the work.

\section{Funding}

The authors thank School of Graduate Studies, Mekelle University for granting sponsorship to the first author. We also thank Norad small research project office for partly supporting the study financially. Funding bodies did not involve in the study design and collection, analysis, and interpretation of data.

\section{Availability of data and materials}

The datasets generated and/or analyzed during the study are available from the corresponding author on reasonable request.

\section{Ethics approval and consent to participate}

The protocol approval letter was obtained from the Health Research Ethics Review Committee (HRERC) of College of Health Sciences, Mekelle University and registered as ERC 1537/2018 protocol number on December 11, 2018. In addition, to avoid animal suffering at each stage of the experiment, the internationally accepted laboratory animal care and use guideline was used.

\section{Consent for publication}

Not applicable.

\section{Competing interests}

The authors declare that they have no conflicts of interest.

Received: 5 November 2019 Accepted: 25 June 2020

Published online: 30 June 2020

\section{References}

1. WHO. Key facts Scope of diarrhoeal disease. World Heal Organ / Centers Dis Control Prev. 2017; http://www.who.int/news-room/fact-sheets/detail/ diarrhoeal-disease.

2. Sweetser S. Evaluating the patient with diarrhea: a case-based approach. Mayo Clin Proc. 2012:87:596-602.

3. Reintam Blaser A, Deane AM, Fruhwald S. Diarrhoea in the critically ill. Curr Opin Crit Care. 2015:21:142-53.

4. GBD. Estimates of global, regional, and national morbidity, mortality, and aetiologies of diarrhoeal diseases: a systematic analysis for the Global Burden of Disease Study 2015. Lancet Infect Dis. 2017;17:909-48.

5. Centre for Disease Control and Prevention. Diarrhea: Common Illness, Global Killer. Centers Dis Control Prev. 2012;1-4. https://www.cdc.gov/ healthywater/pdf/global/programs/globaldiarrhea508c.pdf.

6. Shane AL, Mody RK, Crump JA, Tarr PI, Steiner TS, Kotloff K, et al. 2017 Infectious Diseases Society of America Clinical Practice Guidelines for the Diagnosis and Management of Infectious Diarrhea. Clin Infect Dis. 2017;65: e45-80. https://doi.org/10.1093/cid/cix669

7. Riddle MS, Dupont HL, Connor BA. ACG Clinical Guideline : Diagnosis Treatment, and Prevention of Acute Diarrheal Infections in Adults. Am J Gastroenterol. 2016;111:602-22. https://doi.org/10.1038/ajg.2016.126.

8. Falk E. Traditional Medicine - Sharing Experience from the Field. first. Seohak-Ro, Wansan-Gu, Jeonju, Republic of Korea; 2017.

9. Yuan $H, M a$ Q, Ye L, Piao G. The Traditional Medicine and Modern Medicine from Natural Products. Molecules. 2016;21:1-18.

10. Sisay $M$, Engidawork $E$, Shibeshi W. Evaluation of the antidiarrheal activity of the leaf extracts of Myrtus communis Linn (Myrtaceae) in mice model. BMC Complement Altern Med. 2017;17:1-11.

11. Tadesse E, Engidawork E, Nedi T, Mengistu G. Evaluation of the antidiarrheal activity of the aqueous stem extract of Lantana camara Linn ( Verbenaceae ) in mice. BMC Complement Altern Med. 2017;17:1-8.

12. Degu A, Engidawork E, Shibeshi W. Evaluation of the anti-diarrheal activity of the leaf extract of Croton macrostachyus Hocsht . ex Del . ( Euphorbiaceae ) in mice model. BMC Complement Altern Med. 2016:16:1-11.

13. Mishra CK, Sasmal D. In-vivo evaluation of anti-diarrhoeal activity of Ethanolic fruit and root extracts of Carissa carandas Linn. (Apocynaceae). Int J Drug Dev Res. 2015;7:216-21.

14. Tadesse WT, Hailu AE, Gurmu AE, Mechesso AF. Experimental assessment of antidiarrheal and antisecretory activity of $80 \%$ methanolic leaf extract of Zehneria scabra in mice. BMC Complement Altern Med. 2014;14:1-8.

15. Yacob T, Shibeshi W, Nedi T. Antidiarrheal activity of $80 \%$ methanol extract of the aerial part of Ajuga remota Benth (Lamiaceae) in mice. BMC Complement Altern Med. 2016;16:1-8. https://doi.org/10.1186/s12906-016-1277-8.

16. Derebe D, Abdulwuhab M, Wubetu M, Mohammed F. Investigation of the Antidiarrheal and Antimicrobial Activities of $80 \%$ Methanolic Leaf Extract of Discopodium Penninervum (Hochst.) . Evidence-Based Complement. Altern Med. 2018;2018:1-7.

17. Rehman N, Mehmood MH, Alkharfy KM, Gilani A. Studies on antidiarrheal and antispasmodic activities of Lepidium sativum crude extract in rats. Phytother Res. 2012;26:136-41.

18. Tadesse H. Phytochemical Investigation on the Seeds of Brucea antidysenterica. Addis Ababa Univ; 2005. p. 1-53. http://etd.aau.edu.et/ bitstream/handle/123456789/1963/Haregewine\%20Tadesse.pdf?sequence= $1 \&$ isAllowed $=y$.

19. Ablat A, Mohamad J, Awang K, Shilpi JA, Arya A. Evaluation of antidiabetic and antioxidant properties of Brucea javanica seed. Sci World J. 2014;2014 786130. 
20. Kefe A, Giday M, Mamo H, Erko B. Antimalarial properties of crude extracts of seeds of Brucea antidysenterica and leaves of Ocimum lamiifolium. BMC Complement Altern Med. 2016;16:1-8. https://doi.org/10.1186/s12906-016-1098-9.

21. Taye B, Giday M, Animut A, Seid J. Antibacterial activities of selected medicinal plants in traditional treatment of human wounds in Ethiopia. Asian Pac J Trop Biomed. 2011;1:370-5. https://doi.org/10.1016/S2221-1691(11)60082-8.

22. Fentahun M, Yilkal BA, Amsalu N, Alemayehu A, Amsalu G. Antibacterial evaluation and phytochemical analysis of selected medicinal plants against some pathogenic enteric Bacteria in Gozamin District, Ethiopia. Aust J Pharm. 2017:5:1-6.

23. Ayele $T$, Regasa MB, Delesa DA. Antibacterial and antagonistic activity of selected traditional medicinal plants and herbs from east Wollega zone against clinical isolated human pathogens. Sci Technol Arts Res J. 2015;4:175-9.

24. Gillin FD, Reiner DS, Suffness M. Bruceantin , a Potent Amoebicide from a Plant , Brucea antidysenterica. Antimicrob AGENTS Chemother. 1982;22:342-5.

25. Lee KH. Current developments in the discovery and Design of new Drug Candidates from plant natural product leads. J Nat Prod. 2004;67:273-83.

26. Teklehaymanot T. Ethnobotanical study of knowledge and medicinal plants use by the people in Dek Island in Ethiopia. J Ethnopharmacol J. 2009;124: 69-78.

27. Amsalu N, Bezie Y, Fentahun M, Alemayehu A, Amsalu G. Use and Conservation of Medicinal Plants by Indigenous People of Gozamin Wereda, East Gojjam Zone of Amhara Region, Ethiopia: An Ethnobotanical Approach. Evidence-Based Complement Altern Med. 2018;2018:1-23. https://doi.org/ 10.1155/2018/2973513

28. Getaneh S, Girma Z. An ethnobotanical study of medicinal plants in Debre Libanos Wereda, Central Ethiopia. African J Plant Sci. 2014;8:366-79.

29. Woldeab B, Regassa R, Alemu T, Megersa M. Medicinal plants used for treatment of Diarrhoeal related diseases in Ethiopia. Evid Based Complement Altern Med. 2018:2018:1-20.

30. ILAR. The 1996 Guide for the Care and Use of Laboratory Animals. ILAR J. 1996:38:41-8. https://doi.org/10.1093/ilar.38.1.41.

31. OECD. Acute oral toxicity-up-and-down-procedure (UDP). OECD Guidel Test Chem. 2008:425:1-27.

32. Umer S, Tekewe A, Kebede N. Antidiarrhoeal and antimicrobial activity of Calpurnia aurea leaf extract. BMC Complement Altern Med. 2013;13:1-5.

33. Than A, Kulkarni HJ, Hmone W, Tha SJ. Anti-diarrhoea1 Eflicacy of Some Burmese Indigenous Drug Formulations in Experimental Diarrhoea1 Test Models. Int J Crude Drug Res. 1989;27:195-200.

34. CLSI. M07-A10: Methods for Dilution Antimicrobial Susceptibility Tests for Bacteria That Grow Aerobically. Approved Stand. 2015;35:1-87 http://shop. clsi.org/site/Sample_pdf/M07A10_sample.pdf.

35. Molla Y, Nedi T, Tadesse G, Alemayehu H, Shibeshi W. Evaluation of the in vitro antibacterial activity of the solvent fractions of the leaves of Rhamnus prinoides $L$ ' Herit ( Rhamnaceae ) against pathogenic bacteria. BMC Complement Altern Med. 2016;16:1-9. https://doi.org/10.1186/s12906-016-1279-6.

36. CLSI. M100-S25 performance standards for antimicrobial. Wayne: Clinical and Laboratory Standards Institute; 2015.

37. Harborne J. A guide to modern techniques of plant analysis; 1998

38. Asmerom D, Hailu GS, Yimer EM, Bitew H, Kahsay G. Antimicrobial evaluation of latex and TLC fractions from the leaves of Aloe adigratana Reynolds. Evid Based Complement Altern Med. 2020;2020. https://doi.org/ 10.1155/2020/8312471

39. Koné WM, Atindehou KK, Terreaux C, Hostettmann K, Traoré D, Dosso M. Traditional medicine in north $C^{\wedge}$ ote-d ' Ivoire : screening of 50 medicinal plants for antibacterial activity. J Ethnopharmacol. 2004;93:43-9.

40. Eloff JN. Avoiding pitfalls in determining antimicrobial activity of plant extracts and publishing the results. BMC Complement Altern Med. 2019;19: 1-8. https://doi.org/10.1186/s12906-019-2519-3.

41. Sarin RV, Bafna PA. Herbal Antidiarrhoeals : a review. Int J Res Pharm Biomed Sci. 2012;3:637-49.

42. Elmi OE, Dioso R(II)P. Prevalence of Diarrhoeal Diseases Among Children under Five Years in East African Countries from 2012-2017. Asean J Sci Technol Dev. 2017:34:51.

43. Thouri A, Chahdoura H, El Arem A, Omri Hichri A, Ben Hassin R, Achour L. Effect of solvents extraction on phytochemical components and biological activities of Tunisian date seeds (var. Korkobbi and Arechti). BMC Complement Altern Med. 2017;17:1-10.

44. Ashish M, Vinit S, Kritika HEM, Kumar MS. Plants used for treatment of diarrhea : an Ayurvedic prospective plants used for treatment of diarrhea : an ayurvedic prospective. Innovare J Ayurvedic Sci. 2015;3:1-6.
45. Racusen LC, Binder HJ. Ricinoleic acid stimulation of active anion secretion in colonic mucosa of the rat. J Clin Invest. 1979:63:743-9.

46. Van Tonningen MR. Gastrointestinal and antilipidemic agents and spasmolytics. In: Drugs During Pregnancy and Lactation. 2nd ed: Elsevier B. V; 2007. p. 94-122. https://doi.org/10.1016/B978-044452072-2/50009-4.

47. Tunaru S, Althoff TF, Nusing RM, Diener M, Offermanns S. Castor oil induces laxation and uterus contraction via ricinoleic acid activating prostaglandin EP3 receptors. Proc Natl Acad Sci. 2012;109:9179-84. https://doi.org/10.1073/ pnas.1201627109.

48. Harig JM, Ramaswamy K. Acute diarrhea in adults. Postgrad Med. 2016;86: 131-40. https://doi.org/10.1080/00325481.1989.11704502.

49. Lakshmanan B, Mazumder PM, Sasmal D, Ganguly S. Synthesis, antispasmodic and antidiarrheal activities of some 1-substituted imidazole derivatives. Acta Pharma. 2011;61:227-36.

50. Schiller LR, Pardi DS, Spiller R, Semrad CE, Surawicz CM, Giannella RA, et al. Gastro 2013 APDWNCOG Shanghai working party report: chronic diarrhea: definition, classification, diagnosis. J Gastroenterol Hepatol. 2014;29:6-25.

51. Faure C. Role of Antidiarrhoeal drugs as adjunctive therapies for acute Diarrhoea in children. Int J Pediatr. 2013;2013:1-14.

52. Beubler E. Role of Prostaglandins in Intestinal Fluid Secretion. In: Domschke W, et al., editors. Prostaglandins and Leukotrienes in Gastrointestinal Diseases; 2011. p. 44-7.

53. Gunaydin C, Bilge SS. Effects of nonsteroidal anti-inflammatory drugs at the molecular level. Eurasian J Med. 2018;50:116-21. https://doi.org/10.5152/ eurasianjmed.2018.0010

54. Tessema Z, Makonnen E, Debella A, Molla Y. Evaluation of in vivo wound healing and anti-inflammatory activity of crude extract of the fruits of Brucea antidysentrica in mice. Wound Med. 2018;21:16-21. https://doi.org/ 10.1016/j.wndm.2018.05.005.

55. Mummed B, Abraha A, Feyera T, Nigusse A, Assefa S. In Vitro Antibacterial Activity of Selected Medicinal Plants in the Traditional Treatment of Skin and Wound Infections in Eastern Ethiopia. Biomed Res Int. 2018;2018:1-8. https://doi.org/10.1155/2018/1862401

56. Yemata G, Fetene M. In vitro evaluation of the antibacterial activity of some medicinal plant extracts against Xanthomonas campestris pv. musacearum. Ethiop J Sci Technol. 2017;10:17.

57. Famuyide IM, Aro AO, Fasina FO, Eloff JN, Mcgaw LJ. Antibacterial activity and mode of action of acetone crude leaf extracts of under- investigated Syzygium and Eugenia ( Myrtaceae ) species on multidrug resistant porcine diarrhoeagenic Escherichia coli. BMC Vet Res. 2019;15:1-14 https://doi.org/ 10.1186/s12917-019-1914-9.

58. Adlard PA, Kirov SM, Sanderson K, Cox GE. Pseudomonas aeruginosa as a cause of infectious diarrhoea. Epidemiol Infect. 1998;121:237-41.

59. Pang Z, Raudonis R, Glick BR, Lin T, Cheng Z. Antibiotic resistance in Pseudomonas aeruginosa : mechanisms and alternative therapeutic strategies. Biotechnol Adv. 2019;37:177-92. https://doi.org/10.1016/j. biotechadv.2018.11.013.

60. Carlos CC, Saniel MC. Etiology and epidemiology of diarrhea. Phil JMicrobiol Infect Dis. 1990;19:51-3.

61. Cooke. Causes and management of diarrhoea in children in a clinical setting. S Afr J Clin Nutr. 2010;23:42-6.

62. Diemert DJ. Prevention and self-treatment of traveler ' $s$ diarrhea. Am Soc Microbiol. 2006:19:583-94.

63. Bakare RI, Magbagbeola OA, Akinwande Al, Okunowo OW, Green M. Antidiarrhoeal activity of aqueous leaf extract of Momordica charantia in rats. J Pharmacogn Phyther. 2011;3:1-7.

64. Palombo EA. Phytochemicals from Traditional Medicinal Plants used in the Treatment of Diarrhoea : Modes of Action and Effects on Intestinal Function. Phytother Res. 2006;724:717-24.

65. Hossain E, Ko SY, Yang CJ. Dietary supplementation of green tea byproducts on growth performance, meat quality, blood parameters and immunity in finishing pigs. J Med Plants Res. 2012;6:2458-67.

\section{Publisher's Note}

Springer Nature remains neutral with regard to jurisdictional claims in published maps and institutional affiliations. 